\title{
Release and regulation of leptin, resistin and adiponectin from human placenta, fetal membranes, and maternal adipose tissue and skeletal muscle from normal and gestational diabetes mellitus-complicated pregnancies
}

\author{
Martha Lappas, Kirin Yee, Michael Permezel and Gregory E Rice \\ Department of Obstetrics and Gynaecology, University of Melbourne and Mercy Perinatal Research Centre, Mercy Hospital for Women, \\ 126 Clarendon Street, East Melbourne, 3002 Victoria, Australia \\ (Requests for offprints should be addressed to M Lappas; Email: mlappas@unimelb.edu.au)
}

\begin{abstract}
The aim of this study was to determine the release and regulation of leptin, resistin and adiponectin from human placenta and fetal membranes, and maternal subcutaneous adipose tissue and skeletal muscle obtained from normal and gestational diabetes mellitus (GDM)-complicated pregnancies at the time of Cesarean section. Tissue explants were incubated in the absence (basal control) or presence of $10 \mu \mathrm{g} / \mathrm{ml}$ lipopolysaccharide (LPS), 10, 20 or $40 \mathrm{ng} / \mathrm{ml}$ tumor necrosis factor- $\alpha$ (TNF- $\alpha$ ), interleukin (IL)-6 and IL-8, $1 \mu \mathrm{M}$ phorbol myristate acetate, 10, 20 and $40 \mathrm{mM}$ glucose, $0 \cdot 1,1$ and $10 \mu \mathrm{M}$ insulin and $0 \cdot 11$ and $10 \mu \mathrm{M}$ dexamethasone, progesterone and estrogen. After an 18-h incubation, the medium was collected and the release of leptin, resistin and adiponectin was quantified by ELISA. Human gestational tissues and maternal tissues released immunoreactive leptin, resistin and adiponectin; however, there was no difference in the release of either resistin or adiponectin between normal pregnant women and women with gestational diabetes. The release of leptin was significantly higher in placenta, amnion and choriodecidua obtained from normal pregnant women
\end{abstract}

compared with women with GDM. However, in maternal tissues, the situation was reversed, with adipose tissue and skeletal muscle obtained from women with GDM releasing significantly greater amounts of leptin. In adipose tissue and skeletal muscle the release of leptin was significantly greater in insulin-controlled GDM compared with diet-controlled GDM, and leptin release from adipose tissue was significantly correlated with maternal body mass index. In all tissues tested, there was no effect of incubation with LPS, IL-6, IL-8 or TNF- $\alpha$ on leptin, resistin or adiponectin release. PMA significantly increased the release of resistin from placenta and adipose tissue. Insulin increased placental resistin release, whereas the hormones dexamethasone, progesterone and estrogen significantly decreased placental resistin release. The data presented in this study demonstrate that dysregulation of leptin metabolism and/or function in the placenta may be implicated in the pathogenesis of GDM. Furthermore, resistin release is greatly affected by a variety of inflammatory mediators and hormones.

Journal of Endocrinology (2005) 186, 457-465

\section{Introduction}

Recent investigations have focused on several new potential mediators of insulin resistance including leptin, resistin and adiponectin. Leptin, resistin and adiponectin are known to be produced within the intrauterine environment (Masuzaki et al. 1997, Lea et al. 2000, Lepercq et al. 2001, Akerman et al. 2002, Lindsay et al. 2003, Yura et al. 2003); however their expression and regulation in gestational tissues and in relation to gestational diabetes mellitus (GDM) remains to be fully elucidated.

Leptin was originally discovered as a protein involved in the development of obesity, and although it is now recognized as a hormone that is produced by several tissues, adipose tissue is the principal site of leptin production and the major determinant of the level of circulating hormone (Wauters et al. 2000). The functions attributed to leptin are extensive, including the regulation of food intake and energy balance through central hypothalamic pathways, acting as a major signal to the reproductive system, inhibition of insulin secretion by pancreatic $\beta$-cells, and stimulation of glucose transport (reviewed in Wauters et al. 2000). Leptin is produced in the human placenta and is secreted into both the maternal and fetal circulation (Masuzaki et al. 1997). Expression of leptin has been identified in placenta, chorionic villi, chorion laeve and amnion (Akerman et al. 2002). Human leptin mRNA and protein are also localized to the villous vascular 
endothelial cells, which are in direct contact with the fetal blood (Lea et al. 2000). Both long and short leptin receptor $(\mathrm{Ob}-\mathrm{R})$ isoforms are present in placenta, and are co-localized with leptin to the syncytiotrophoblast at the maternal interface (Bodner et al. 1999, Lea et al. 2000), implicating a potential autocrine or paracrine effect of leptin on placental function.

Resistin is a recently discovered protein that is secreted by adipocytes, and is thought to impair glucose tolerance (Steppan et al. 2001). Resistin induces severe hepatic, but not peripheral, insulin resistance. Furthermore, initial studies demonstrated that resistin is up-regulated in both genetic and diet-induced obesity in vivo and downregulated by the anti-diabetic agents, the thiazolidinediones (TZDs) (Steppan et al. 2001). These studies by Steppan and colleagues led to the hypothesis that resistin might be a link between obesity and diabetes, as well as a candidate to explain the anti-diabetic effects of TZDs. However, subsequent studies have failed to show an association with resistin and diabetes. In particular, it is not clear whether human adipocytes express substantial amounts of resistin mRNA and protein, and studies on the regulation of resistin are contradictory (reviewed in Fasshauer \& Paschke 2003).

Adiponectin is another protein that is secreted by adipocytes, and is postulated to play a role in the modulation of glucose and lipid metabolism in insulin-sensitive tissues in both humans and animals. In humans, plasma adiponectin concentrations exceed those of any other hormone by a thousand times; they decrease in insulinresistant states including type II diabetes mellitus, and are positively associated with whole-body insulin sensitivity (Hu et al. 1996, Weyer et al. 2001).

Leptin and adiponectin levels are dysregulated in pathological conditions such as GDM, pre-eclampsia and intrauterine growth restriction, representing an effect or a cause of disturbances in the feto/placento/maternal unit (Festa et al. 1999, Lea et al. 2000, Lepercq et al. 2001, Chan et al. 2003, Pighetti et al. 2003, Ranheim et al. 2004, Williams et al. 2004). Furthermore, a variety of hormones, cytokines and inflammatory stimuli have also been shown to regulate leptin, resistin and adiponectin expression and release. Therefore, we hypothesize that the release of leptin, resistin and adiponectin may be affected by a number of factors, including GDM, glucose, and hormones and inflammatory stimuli known to affect insulin sensitivity. Therefore, the main purpose of this study was to investigate the release and regulation of leptin, resistin and adiponectin from placenta, fetal membranes, adipose tissue and skeletal muscle. A well characterized tissue explant system is used to determine the effect of cytokine stimulation (tumor necrosis factor- $\alpha$ (TNF- $\alpha$ ), interleukin (IL)-6 and IL-8), glucose treatment, hormone stimulation (insulin, progesterone, dexamethasone and estrogen) and phorbol myristate acetate (PMA) induction on leptin, resistin and adiponectin release from placenta and fetal membranes (amnion and choriodecidua), and maternal subcutaneous adipose tissue and skeletal muscle tissue from normal pregnant women and women with GDM.

\section{Materials and Methods}

\section{Reagents}

All chemicals were purchased from BDH Chemicals Australia (Melbourne, Victoria, Australia) unless otherwise stated. RPMI 1640 (glucose free) was obtained from Gibco Laboratories (Grand Island, NY, USA). BSA (RIA grade), dexamethasone (water soluble), estrogen (water soluble), human recombinant IL-6, IL-8 and TNF- $\alpha$, insulin (from bovine pancreas), lipopolysaccharide (LPS), $\beta$-NADH (disodium salt), 3,3',5,5'-tetramethylbenzidine (TMB), progesterone (water soluble) and pyruvic acid (dimer free) were supplied by Sigma (St Louis, MO, USA). PMA and 4 $\alpha$-PMA were purchased from Tocris (Ellisville, MO, USA). The leptin kit was supplied by Biosource International (Camarillo, CA, USA). The resistin and adiponectin ELISA kits were supplied by CytoLab (Rehovot, Israel) and R\&D Systems (Minneapolis, MN, USA) respectively.

\section{Patients and samples}

Human placenta with attached fetal membranes, subcutaneous adipose tissue (from the anterior abdominal wall), skeletal muscle (pyramidalis, small muscle of the anterior abdomen wall), and maternal blood were obtained from a total of 30 pregnant women (15 normal and 15 with GDM) who delivered healthy, singleton infants at term (>37 weeks gestation) undergoing elective Cesarean section (indications for Cesarean section were breech presentation and/or previous Cesarean section). Women with GDM were diagnosed according to the criteria of the Australasian Diabetes in Pregnancy Society by either a fasting venous plasma glucose level of $\geq 5.5 \mathrm{mmol} / 1$ glucose, and/or $\geq 8.0 \mathrm{mmol} / 1$ glucose $2 \mathrm{~h}$ after a $75 \mathrm{~g}$ oral glucose load. Approval for this study was obtained from the Mercy Hospital for Women's Research and Ethics Committee and informed consent was obtained from all participating subjects.

\section{Tissue explants}

Tissues were obtained within $10 \mathrm{~min}$ of delivery and dissected fragments were placed in ice-cold PBS. Tissues were dissected to remove visible connective tissue, vessels and/or calcium deposits. Tissue fragments were placed in RPMI (gestational tissues) or DMEM (maternal tissues) containing $5 \mathrm{mM}$ glucose at $37^{\circ} \mathrm{C}$ in a humidified atmosphere of carbogen gas $\left(95 \% \mathrm{O}_{2}\right.$ and $\left.5 \% \mathrm{CO}_{2}\right)$ for $1 \mathrm{~h}$. Explants were blotted dry on sterile filter paper and 
transferred to 24-well tissue culture plates (100-200 mg wet weight/well). The explants were incubated, in duplicate, in $2 \mathrm{ml}$ media containing penicillin $\mathrm{G}(100 \mathrm{U} / \mathrm{ml})$ and streptomycin $(100 \mu \mathrm{g} / \mathrm{ml})$, in the absence (basal release) or presence of $10 \mu \mathrm{g} / \mathrm{ml}$ LPS, 10,20 and $40 \mathrm{ng} / \mathrm{ml}$ IL-6, IL-8 and TNF- $\alpha, 1 \mu \mathrm{M}$ PMA or $1 \mu \mathrm{M} 4 \alpha$-PMA (inactive PMA analog), 10, 20 and $40 \mu \mathrm{M}$ glucose and $0 \cdot 1$, 10 and $10 \mu \mathrm{M}$ insulin, dexamethasone, progesterone and estrogen. Time course experiments showed that an 18-h incubation was optimal for hormone release. Following an 18-h incubation, tissues were collected and assayed for total protein, while the incubation media were collected and assayed for leptin, resistin and adiponectin release by ELISA.

\section{Validation of explant cultures and viability}

To determine the effect of experimental treatment on cell membrane integrity, the release of the intracellular enzyme lactate dehydrogenase (LDH) into the incubation medium was determined as described previously (Lappas et al. 2004). Data are presented as a percentage of total tissue LDH. LDH release was investigated over the 18 -h time course of tissue explants $(n=3)$. In vitro incubation did not significantly affect LDH activity in the incubation media with none of these measurements exceeding $7 \%$ of total activity present in the tissue (data not shown). These data indicate that the concentrations used in this study did not affect cell viability.

\section{Experimental assays}

The release of leptin (Biosource International), resistin (CytoLab) and adiponectin (R\&D Systems) into the explant incubation medium was determined by sandwich ELISA according to the manufacturers' instructions. The intra- and interassay coefficients of variation for the leptin ELISA were $3.4 \%$ and $4.5 \%$ respectively, and the minimum detectable limit of the assay was $7 \cdot 2 \mathrm{pg} / \mathrm{ml}$. The intra- and interassay coefficients of variation for the resistin ELISA were $3.4 \%$ and $4.5 \%$ respectively, and the minimum detectable limit of the assay was $16 \mathrm{pg} / \mathrm{ml}$. The intra- and interassay coefficients of variation for the adiponectin ELISA were $4 \cdot 2 \%$ and $4 \cdot 7 \%$ respectively, and the minimum detectable limit of the assay was $32 \mathrm{pg} / \mathrm{ml}$. All tissue release data were corrected for total protein and expressed as pg per mg protein for leptin and resistin or ng per $\mathrm{mg}$ protein for adiponectin. The protein content of tissue homogenates was determined using the bicinchoninic acid protein assay (Pierce, Rockford, IL, USA), using BSA as a reference standard, as previously described (Lappas et al. 2004).

\section{Statistical analysis}

Statistical analyses were performed using a commercially available statistical software package (Statgraphics, Stat
Point Inc., Herndon, VA, USA). Homogeneity of data was assessed by Bartlett's test, and when significant, data were logarithmically transformed before further analysis by oneway analysis of variance (ANOVA). Two sample comparisons were analyzed using Student's $t$-test. Linear regression analyses were used to evaluate the relationship among the variables of interest. Statistical difference was indicated by a $P$ value of less than $0 \cdot 05$. Data are expressed as means \pm standard error of the mean (S.E.M.).

\section{Results}

\section{Participants}

Demographic data of the participants involved in the investigation are summarized in Table 1 . The characteristics of this study group relate to the data obtained in part 1 of this study. There were no significant differences in maternal age, maternal body mass index (BMI), fetal birth weight and gestational age between normal pregnant women and women with GDM. Fasting, one-hour and two-hour plasma glucose concentrations after an oral glucose tolerance test were significantly greater in women with GDM compared with healthy pregnant women. Significantly greater maternal plasma insulin levels and significantly lower serum adiponectin levels were observed in women with GDM. Maternal serum leptin and resistin levels were not significantly different between normal pregnant women and women with GDM.

\section{Part 1: basal hormone release from gestational and maternal} tissues

Basal leptin release from gestational and maternal tissues With respect to human gestational tissues, placental tissues released the greatest amount of leptin compared with amnion and choriodecidua (Fig. 1). In all three tissues, the basal release of leptin was significantly greater in women with normal pregnancies $(n=7)$, compared with women with GDM $(n=11)$.

Figure 2a demonstrates that leptin release from both adipose tissue and skeletal muscle collected from women with GDM $(n=9)$ was significantly greater than the release from normal pregnant women $(n=9)$. Furthermore, as demonstrated in Fig. 2b, there was significantly more leptin released from tissue explants in women with GDM who were treated with insulin $(n=5)$ compared with women who were managed by dietary modification alone $(n=4)$. In regression analysis (Fig. 3), the release of leptin from adipose tissue was significantly correlated with maternal BMI from normal pregnant women and women with GDM combined $(n=18 ; r=0 \cdot 71, P=0 \cdot 02)$.

Basal resistin release from gestational and maternal tissues Immunoreactive resistin was detected in all gestational and maternal tissue samples assayed; however, there 
Table 1 Characteristics of the study group. Values represent means \pm S.E.M.

\begin{tabular}{|c|c|c|c|}
\hline & $\begin{array}{l}\text { Control patients } \\
(n=9)\end{array}$ & $\begin{array}{l}\text { GDM patients* } \\
(n=11)\end{array}$ & $P$ values§ \\
\hline Maternal age (years) & $31 \cdot 7 \pm 1 \cdot 3$ & $35 \cdot 9 \pm 1 \cdot 7$ & NS \\
\hline Maternal BMI† $\left(\mathrm{kg} / \mathrm{m}^{2}\right)$ & $28 \cdot 5 \pm 2 \cdot 6$ & $24 \cdot 8 \pm 1 \cdot 5$ & NS \\
\hline Gestational age at birth (weeks) & $38 \cdot 7 \pm 0 \cdot 3$ & $38 \cdot 8 \pm 0 \cdot 4$ & NS \\
\hline Fetal birth weight (g) & $3287 \pm 160$ & $3402 \pm 165$ & NS \\
\hline Male & $4 / 9$ & $6 / 11$ & \\
\hline Female & $5 / 9$ & $5 / 11$ & \\
\hline Fasting plasma glucose $(\mathrm{mmol} / \mathrm{l})$ & $4 \cdot 5 \pm 0 \cdot 2$ & $5 \cdot 0 \pm 0 \cdot 2$ & $<0.05$ \\
\hline 1 hour plasma glucose $(\mathrm{mmol} / \mathrm{l})$ & $6 \cdot 8 \pm 0 \cdot 7$ & $9 \cdot 8 \pm 0 \cdot 3$ & $<0 \cdot 05$ \\
\hline 2 hour plasma glucose $(\mathrm{mmol} / \mathrm{l})$ & $5 \cdot 8 \pm 0 \cdot 4$ & $8 \cdot 6 \pm 0 \cdot 1$ & $<0.05$ \\
\hline Maternal serum insulin $(\mu \mathrm{U} / \mathrm{ml})$ & $15 \cdot 3 \pm 2 \cdot 4$ & $25 \cdot 6 \pm 2 \cdot 9$ & $<0.05$ \\
\hline Maternal serum leptin $(\mathrm{ng} / \mathrm{ml})$ & $35 \cdot 5 \pm 10 \cdot 8$ & $24 \cdot 6 \pm 5 \cdot 5$ & NS \\
\hline Maternal serum resistin $(\mathrm{ng} / \mathrm{ml})$ & $3 \cdot 4 \pm 0 \cdot 8$ & $2 \cdot 3 \pm 0 \cdot 2$ & NS \\
\hline Maternal serum adiponectin $(\mu \mathrm{g} / \mathrm{ml})$ & $4 \cdot 7 \pm 0 \cdot 5$ & $3 \cdot 2 \pm 0 \cdot 4$ & $<0.05$ \\
\hline
\end{tabular}

*Eight diet controlled GDM and seven insulin-controlled GDM patients; §Student's $t$-test; †based on first antenatal vist at approximately 12 weeks. NS, not significant.

was no significant difference in the release of resistin from tissues obtained from normal pregnant women and from women with GDM (data not shown). When the data from normal pregnant women and women with GDM were combined, basal resistin release from adipose tissue $(1396 \cdot 1 \pm 325 \cdot 1 \mathrm{ng} / \mathrm{ml})$ was significantly greater than that from skeletal muscle $(665 \cdot 3 \pm 107 \cdot 9 \mathrm{ng} / \mathrm{ml})$. With respect to intrauterine tissues, placenta $(407 \cdot 9 \pm 36 \cdot 0 \mathrm{ng} / \mathrm{ml})$ and choriodecidua $(437 \cdot 1 \pm 43 \cdot 3 \mathrm{ng} / \mathrm{ml})$ released significantly greater amounts of resistin compared with amnion $(203 \cdot 2 \pm 41 \cdot 8 \mathrm{ng} / \mathrm{ml})$.

Basal adiponectin release from gestational and maternal tissues Immunoreactive adiponectin was detected in all gestational and maternal tissue samples assayed. There was no difference in adiponectin released from tissues obtained from normal pregnant women and from women with GDM (data not shown). When the data

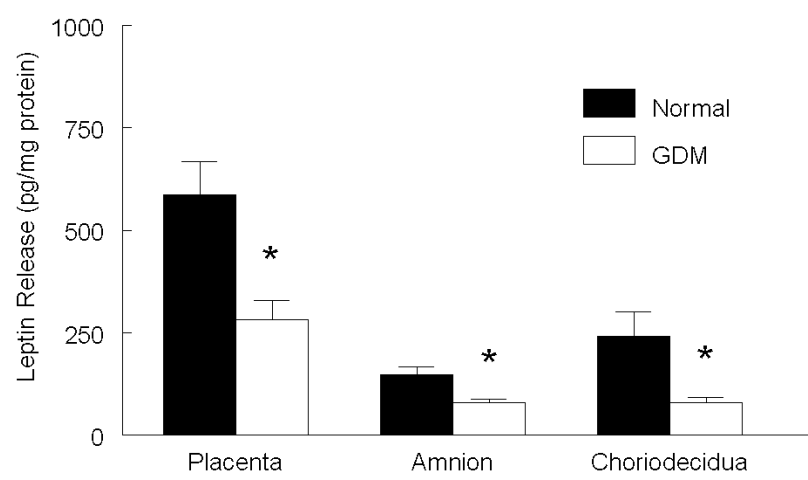

Figure 1 Release of leptin from human placenta, amnion and choriodecidua obtained from normal pregnant women $(n=7)$ and women with GDM $(n=11)$. Each bar represents the mean \pm S.E.M. ${ }^{*} P<0 \cdot 05$ vs leptin release from normal women.
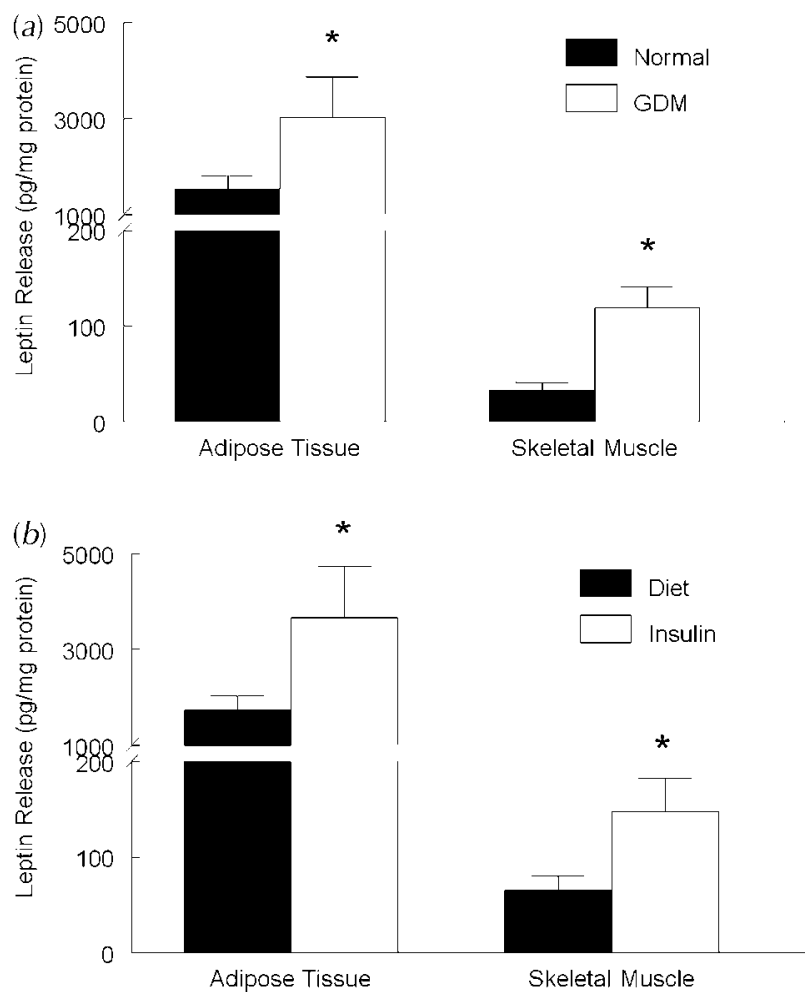

Figure 2 (a) Release of leptin from human subcutaneous adipose tissue and skeletal muscle obtained from normal pregnant women $(n=9)$ and women with GDM $(n=9)$. Each bar represents the mean \pm S.E.M. ${ }^{*} P<0.05$ vs leptin release from normal pregnant women. (b) Release of leptin from human subcutaneous adipose tissue and skeletal muscle obtained from women with insulin-controlled GDM $(n=5)$ and diet-controlled GDM $(n=4)$. Each bar represents the mean \pm S.E.M. ${ }^{*} P<0 \cdot 05$ vs leptin release from diet-controlled GDM. 


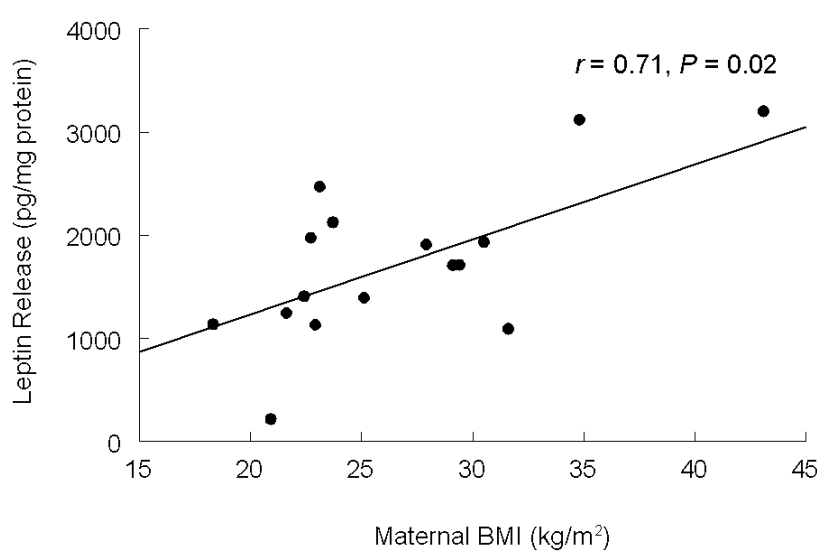

Figure 3 Correlation between maternal $\mathrm{BMI}$ and leptin released from adipose tissue. Data are shown for 9 normal pregnant women and 9 women with GDM $(r=0 \cdot 71, P=0 \cdot 02)$.

from normal pregnant women and women with GDM were combined, basal release of adiponectin from adipose tissue $(26 \cdot 7 \pm 3 \cdot 1 \mu \mathrm{g} / \mathrm{ml})$ was significantly greater than that from skeletal muscle $(17 \cdot 9 \pm 2 \cdot 2 \mu \mathrm{g} / \mathrm{ml})$. Placental adiponectin release $(19 \cdot 3 \pm 1 \cdot 4 \mu \mathrm{g} / \mathrm{ml})$ was significantly greater than that from amnion $(6 \cdot 3 \pm 0.9 \mu \mathrm{g} / \mathrm{ml})$ and choriodecidua $(6 \cdot 8 \pm 0 \cdot 8 \mu \mathrm{g} / \mathrm{ml})$.

\section{Part 2: regulation of hormone release from gestational and} maternal tissues

Effect of LPS and cytokine stimulation on leptin, resistin and adiponectin release Gestational tissues (placenta, amnion, and choriodecidua) were incubated in the presence of $10 \mu \mathrm{g} / \mathrm{ml} \mathrm{LPS}$, and increasing concentrations of TNF- $\alpha$, IL-6 and IL-8 (10, 20 and $40 \mathrm{ng} / \mathrm{ml})$. Due to the small sample size of maternal tissue that was available, adipose tissue and skeletal muscle were incubated in the presence of $10 \mu \mathrm{g} / \mathrm{ml} \mathrm{LPS}$, and $10 \mathrm{ng} / \mathrm{ml}$ TNF- $\alpha$, IL-6 and IL-8. At the concentrations tested in this study, neither LPS nor cytokine stimulation had any effect on leptin, resistin or adiponectin release from gestational and maternal tissues obtained from normal pregnant women and from women with GDM (data not shown).

Effect of high glucose on leptin, resistin and adiponectin release Placenta and adipose tissue obtained from normal pregnant women $(n=5)$ were incubated in the presence of increasing concentrations of glucose $(10,20$ and $40 \mathrm{mM}$ ). There was no effect of glucose on the release of leptin, resistin and adiponectin from placenta or adipose tissue (data no shown).

Effect of insulin on leptin, resistin and adiponectin release Human placentas obtained form normal pregnant women $(n=5)$ were incubated in the presence of increasing concentrations of insulin $(0 \cdot 1,1$ and $10 \mu \mathrm{M})$. There

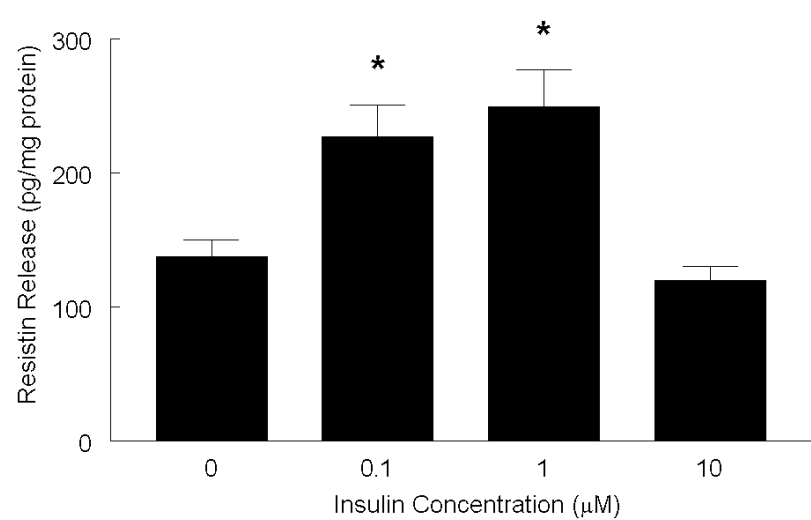

Figure 4 Effect of $0 \cdot 1,1$ and $10 \mu \mathrm{M}$ insulin on the release of resistin from placenta obtained from normal pregnant women $(n=5)$. Each bar represents the mean \pm S.E.M. ${ }^{*} P<0.05$ vs basal resistin release.

was no effect of insulin on the release of leptin and adiponectin (data not shown). There was a biphasic effect of insulin on the release of resistin from human placenta. Insulin at $0 \cdot 1$ and $1 \mu \mathrm{M}$ significantly increased resistin release from human placenta (Fig. 4), whereas at $10 \mu \mathrm{M}$ insulin, resistin release returned to basal levels.

Effect of dexamethasone, progesterone and estrogen on leptin, resistin and adiponectin release Human placentas obtained form normal pregnant women $(n=5)$ were incubated in the presence of increasing concentrations of dexamethasone, progesterone or estrogen $(0 \cdot 1,1$ and $10 \mu \mathrm{M})$. Progesterone, dexamethasone and estrogen, at all concentrations tested, decreased the release of resistin from placenta (Fig. 5), however no effect was observed on the release of leptin and adiponectin (data not shown).

Effect of PMA on leptin, resistin and adiponectin release Human placenta and adipose tissue obtained from normal pregnant women $(n=5)$ were incubated in the

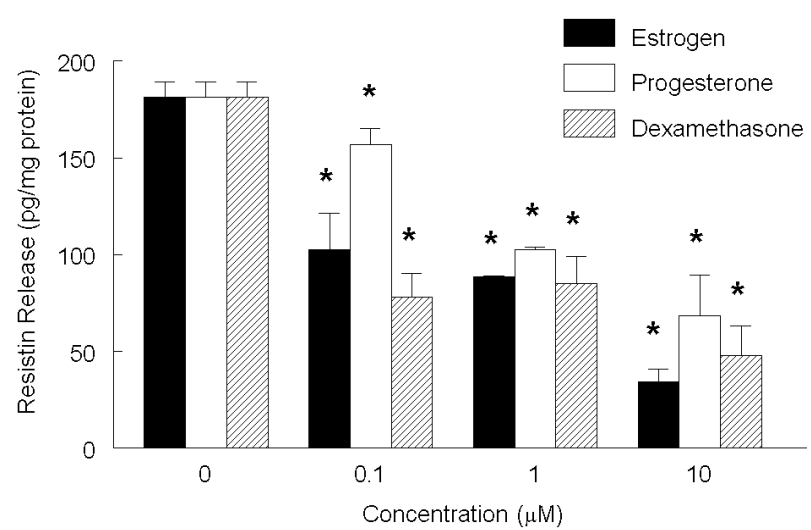

Figure 5 Effect of $0 \cdot 1,1$ and $10 \mu \mathrm{M}$ dexamethasone, progesterone and estrogen treatment on the release of resistin from placenta obtained from normal pregnant women $(n=5)$. Each bar represents the mean \pm S.E.M. ${ }^{*} P<0 \cdot 05$ vs basal resistin release. 


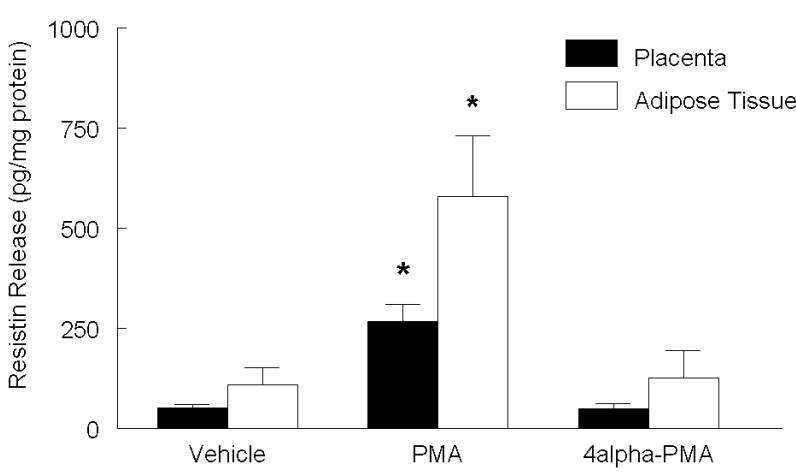

Figure 6 Effect of $1 \mu \mathrm{M}$ PMA and $1 \mu \mathrm{M} 4 \alpha$-PMA on the release of resistin from placenta, and adipose tissue obtained from normal pregnant women $(n=5)$. Each bar represents the mean \pm S.E.M. ${ }^{*} P<0 \cdot 05$ vs basal resistin release.

presence of $1 \mu \mathrm{M}$ PMA, and $1 \mu \mathrm{M}$ of the PMA analog $4 \alpha$-PMA. There was no effect of PMA on the release of leptin and adiponectin from these tissues (data not shown). However, in the presence of $1 \mu \mathrm{M}$ PMA, resistin release was increased from both placenta and adipose tissue (Fig. 6). Furthermore, there was no effect on resistin release upon treatment with $1 \mu \mathrm{M} 4 \alpha$-PMA.

\section{Discussion}

In this study, a well characterized explant system was used to determine the release and regulation of leptin, resistin and adiponectin from human gestational and maternal tissues. The data presented in this study demonstrate that leptin, resistin and adiponectin are released from human placenta and fetal membranes, and from maternal subcutaneous adipose tissues and skeletal muscle obtained from pregnant women. There were no differences in the release of resistin and adiponectin between normal pregnant women and women with GDM; however there is a differential release of leptin from gestational (placenta, amnion and choriodecidua) and maternal (adipose tissue and skeletal muscle) tissues obtained from normal and GDM-complicated pregnancies. In particular, adipose tissue and skeletal muscle from women with GDM produced greater amounts of leptin than normal pregnant women. This is in marked contrast to the situation in gestational tissues, where leptin release was greater in placenta, amnion and choriodecidua obtained from normal pregnant women.

The role of leptin synthesized from the placenta is not clear, although it may have both autocrine and paracrine activities. Although human placental leptin is identical to that of adipose origin on the basis of size, charge and immunoreactivity, and it has the same promoter, it has a placenta-specific upstream enhancer (Bi et al. 1997). This suggests that the placental and adipose leptin gene expres- sions are regulated differently, and therefore placental leptin may play a distinct role in pregnancy. As both the short and long splice variants of the leptin receptor have been localized in human placenta and fetal membranes (Hoggard et al. 1997, Ebenbichler et al. 2002), it suggests a possible role for leptin in fetal growth and development, transport of maternal leptin to the fetus or the removal of leptin from the maternal-fetal circulation (reviewed in Ashworth et al. 2000, Henson \& Castracane 2000).

Previous studies have demonstrated that leptin gene and protein expression are markedly elevated in placentas of women with GDM (Lea et al. 2000, Lepercq et al. 2001). The authors concluded that this may represent a protective response to counter the effects of an imbalance of proinflammatory cytokines which is characteristic of many pathological pregnancies, including GDM. This is, however, in contrast to our findings of decreased leptin release from placenta and fetal membranes from GDMcomplicated pregnancies, and those reported by Festa et al. (1999) who demonstrated that women with mild GDM had lower leptin levels compared with women with normal glucose tolerance. In this study also, maternal serum leptin levels at the time of Cesarean section were lower in women with GDM, although this did not reach significance. There are many possible reasons for the conflicting results between our studies and previous studies with respect to leptin levels and GDM. Previous studies have looked at the mRNA or protein expression of leptin in placentas of women with GDM (Lea et al. 2000, Lepercq et al. 2001), whereas in this study, we investigated the release from placental explants. Tissue explants are not comprised of just one cell type and paracrine mediators produced by, for example, non-trophoblast cells present in placenta (such as immunocytes and vascular cells) may be having an effect on leptin release. Furthermore, several hormonal and metabolic changes that occur in insulinresistant women could contribute to the regulation of placental leptin expression.

The expression of leptin receptors may signal differently in pregnancies of normal and diabetic women. Challier et al. (2003) reported that, in contrast with the transmembrane leptin receptor, expression of the soluble receptor is increased in placentas of women with GDM. Soluble leptin receptor is capable of binding leptin with a high affinity. Therefore, it is feasible that this increased expression of soluble leptin receptor may act as a leptin binder, therefore limiting its accessibility to the transmembrane receptor. This, in turn, may modulate the release of leptin from GDM placentas, therefore accounting for the decreased release of leptin observed in this study.

Correlations have been found among plasma leptin level, BMI and adipose tissue mass (particularly subcutaneous fat) in both animals and non-pregnant adults (Hamilton et al. 1995, Lonnqvist et al. 1995, Cseh et al. 2002). Similarly, in this study, the release of leptin from adipose tissue strongly correlated with maternal 
body weight and BMI. As leptin circulates at levels proportionate to body adiposity, it has been postulated that insulin may also regulate adipose tissue leptin secretion. Insulin regulation of leptin mRNA expression has been observed in adipose tissue of rodents and humans (MacDougald et al. 1995, Malmstrom et al. 1995, Saladin et al. 1995), although some studies have failed to find an association between body adiposity and circulating levels of insulin and leptin (Schwartz et al. 1997). In this study, there was a significant difference in leptin release from adipose tissue and skeletal muscle explants in women with GDM who were treated with insulin compared with women who were managed by dietary modification alone. The finding that there was no difference in placenta and fetal membranes suggests that maternal, and not fetal, hyperinsulinemia may be responsible for this regulation. This is in contrast to Lepercq et al. (1998) who demonstrated that placental leptin mRNA and protein contents were increased in women requiring chronic insulin therapy during pregnancy.

Reduced plasma concentrations of adiponectin have been reported in patients with type II diabetes mellitus, and more recently GDM (Ranheim et al. 2004, Williams et al. 2004). In this study, although maternal serum adiponectin levels at the time of Cesarean section were significantly lower in the GDM group, there was no significant difference in the release of adiponectin from gestational and maternal tissues obtained from normal pregnant women and women with GDM. Adiponectin was released from maternal skeletal muscle in significant amounts (approximately 70\% of that secreted by adipose tissue), and it has been suggested that this may represent adiponectin secreted from adipocytes within the skeletal muscle itself. However, these same skeletal muscle samples released very minimal levels of leptin, whereas in adipose tissue the release of leptin was approximately 10-fold.

Leptin, resistin and adiponectin expression and release are known to be affected by a number of inflammatory mediators known to affect insulin sensitivity, including LPS and TNF- $\alpha$. Placental leptin mRNA production is up-regulated by TNF- $\alpha$ and IL-6 (Chardonnens et al. 1999, Soh et al. 2000, Cameo et al. 2003, Nuamah et al. 2004), and although there is little information available on the regulation of resistin and adiponectin within intrauterine tissues, resistin expression is up-regulated by LPS and suppressed by TNF- $\alpha$ (Lu et al. 2002, Shojima et al. 2002, Kaser et al. 2003), and adiponectin gene expression and secretion is inhibited by TNF- $\alpha$ (Kappes \& Loffler 2000, Halleux et al. 2001) and IL-6 (Fasshauer et al. 2003). In this study, there was no effect of LPS or proinflammatory cytokines on the release of leptin, resistin and adiponectin from gestational and maternal tissues. Similarly, Soh et al. (2000) demonstrated that leptin production from placenta, amnion and choriodecidua was unaffected by treatment with IL- $1 \beta$, TNF- $\alpha$ and LPS. There are a number of possible reasons for the lack of a response by leptin, resistin and adiponectin to LPS and pro-inflammatory cytokines in this study. (1) It may suggest that the normal regulatory mechanisms are no longer in place; however, we have previously demonstrated that under the same tissue explant conditions these tissues are in fact viably active as they do respond to these stimuli by increasing the release of TNF- $\alpha$, IL- 6 and/or IL-8 (Lappas et al. 2004). (2) The explant system and the preservation of the extracellular matrix may provide a more natural environment that allows placental cells and adipocytes to respond to stimuli as they would in vivo. (3) Greater concentrations of these inflammatory stimuli, or shorter or longer periods of stimulation, may be required to elicit a response. Lu et al. (2002) demonstrated that the concentration of LPS required to increase resistin gene expression in 3T3-L1 adipocytes was significantly greater than that required to stimulate resistin gene expression in isolated human peripheral blood mononuclear cells (75 $\mathrm{gg} / \mathrm{ml}$ compared with $10 \mathrm{ng} / \mathrm{ml}$ LPS). Furthermore, concentrations of TNF- $\alpha$ as high as $500 \mathrm{ng} / \mathrm{ml}$ have been used to observe increased resistin mRNA expression (Kaser et al. 2003).

Resistin release from placental and adipose tissue was up-regulated by PMA. PMA, a potent activator of protein kinase $\mathrm{C}$ (PKC), increases the release of several cytokines and other cellular mediators such as TNF- $\alpha$ and IL-6 via activation of mitogen-activated protein kinase and nuclear factor-kappa B, (Voon et al. 2004, Wang et al. 2004, Eligini et al. 2005, Kostadinova et al. 2005). It is therefore possible that PMA induces resistin release in placenta and adipose tissue via one of these pathways.

Normal pregnancy, which is associated with high circulating levels of both estrogen and progesterone, is also associated with decreased insulin sensitivity. Dexamethasone, progesterone and estrogen have been proposed to cause insulin resistance by reducing the cellular content of insulin receptor substrate proteins which, in turn, results in a reduction in proximal insulin-stimulated signaling cascades (Collison et al. 2000, Buren et al. 2002, Garcia-Arencibia et al. 2005). Several studies have provided evidence that glucocorticoids may play an important role in the physiological modulation of adipocyokines, and thus insulin resistance. Both in vitro and in vivo studies have demonstrated that hormone treatment results in either stimulation (Machinal et al. 1999, Shojima et al. 2002) or inhibition (Combs et al. 2003, Huang et al. 2005) of leptin, resistin and/or adiponectin secretion, and mRNA and protein expression. In this study, dexamethasone, progesterone and estrogen decreased placental resistin release, but had no effect on leptin and adiponectin release. The present findings suggest that glucocorticoid-induced down-regulation of resistin release may not contribute to insulin resistance in human placenta.

A number of studies have found insulin to be a key regulator of resistin gene expression, although both inhibitory and stimulatory effects have been reported. Insulin 
inhibits resistin gene expression in 3T3-L1 and mouse adipocytes (Haugen et al. 2001, Shojima et al. 2002), whereas in streptozotocin-diabetic mice (Kim et al. 2001) and in Zucker diabetic fatty rats (Way et al. 2001), insulin stimulates resistin gene expression. Likewise, in this study, insulin stimulated the release of resistin from human placenta. Normal pregnancy is considered a state of hyperinsulinemia and insulin resistance, and our finding of increased resistin secretion by insulin is consistent with a role for resistin in the induction of insulin resistance during pregnancy.

The data presented in this study have established that there is a differential release of leptin from fetal and maternal tissues obtained from women with GDM and from normal pregnant women, and dysregulation of leptin metabolism and/or function in the placenta may be implicated in the pathogenesis of GDM. Resistin release is greatly affected by a variety of inflammatory mediators and hormones, but future studies are warranted to elucidate fully the function of leptin, resistin and adiponectin in normal and diabetic pregnancies.

\section{Acknowledgements}

The work described in this manuscript was funded by the Diabetes Australia Research Trust, University of Melbourne Research Grant Scheme, and the Medical Research Foundation for Women and Babies. Dr Martha Lappas is in receipt of a Postdoctoral Research Fellowship from the Elizabeth and Vernon Puzey Foundation. The authors gratefully acknowledge the assistance of the Clinical Research Midwives Val Bryant, Sarah Mitchell, Angie Denning, and Ellen Smith, and the Obstetrics and Midwifery staff of the Mercy Hospital for Women for their co-operation. The authors declare that there is no conflict of interest that would prejudice the impartiality of this scientific work.

\section{References}

Akerman F, Lei ZM \& Rao CV 2002 Human umbilical cord and fetal membranes co-express leptin and its receptor genes. Gynecological Endocrinology 16 299-306.

Ashworth CJ, Hoggard N, Thomas L, Mercer JG, Wallace JM \& Lea RG 2000 Placental leptin. Reviews of Reproduction 5 18-24.

Bi S, Gavrilova O, Gong DW, Mason MM \& Reitman M 1997 Identification of a placental enhancer for the human leptin gene. Journal of Biological Chemistry 272 30583-30588.

Bodner J, Ebenbichler CF, Wolf HJ, Muller-Holzner E, Stanzl U, Gander R, Huter O \& Patsch JR 1999 Leptin receptor in human term placenta: in situ hybridization and immunohistochemical localization. Placenta 20 677-682.

Buren J, Liu HX, Jensen J \& Eriksson JW 2002 Dexamethasone impairs insulin signalling and glucose transport by depletion of insulin receptor substrate-1, phosphatidylinositol 3-kinase and protein kinase B in primary cultured rat adipocytes. European Journal of Endocrinology 146 419-429.
Cameo P, Bischof P \& Calvo JC 2003 Effect of leptin on progesterone, human chorionic gonadotropin, and interleukin-6 secretion by human term trophoblast cells in culture. Biology of Reproduction 68 472-477.

Challier J, Galtier M, Bintein T, Cortez A, Lepercq J \& Hauhuel de Mouzon S 2003 Placental leptin receptor isoforms in normal and pathological pregnancies. Placenta 24 92-99.

Chan TF, Su JH, Chung YF, Hsu YH, Yeh YT, Jong SB \& Yuan SSF 2003 Amniotic fluid and maternal serum leptin levels in pregnant women who subsequently develop preeclampsia. European Journal of Obstetrics, Gynecology, and Reproductive Biology 108 50-53.

Chardonnens D, Cameo P, Aubert ML, Pralong FP, Islami D, Campana A, Gaillard RC \& Bischof P 1999 Modulation of human cytotrophoblastic leptin secretion by interleukin-1 $\alpha$ and $17 \beta$-oestradiol and its effect on hCG secretion. Molecular and Human Reproduction 5 1077-1082.

Collison M, Campbell IW, Salt IP, Dominiczak AF, Connell JMC, Lyall H \& Gould GW 2000 Sex hormones induce insulin resistance in 3T3-L1 adipocytes by reducing cellular content of IRS proteins. Diabetologia 43 1374-1380.

Combs TP, Berg AH, Rajala MW, Klebanov S, Iyengar P, Jimenez-Chillaron JC, Patti ME, Klein SL, Weinstein RS \& Scherer PE 2003 Sexual differentiation, pregnancy, calorie restriction, and aging affect the adipocyte-specific secretory protein adiponectin. Diabetes 52 268-276.

Cseh K, Baranyi E, Melczer Z, Csakany GM, Speer G, Kovacs M, Gero G, Karadi I \& Winkler G 2002 The pathophysiological influence of leptin and the tumor necrosis factor system on maternal insulin resistance: negative correlation with anthropometric parameters of neonates in gestational diabetes. Gynecological Endocrinology 16 453-460.

Ebenbichler CF, Kaser S, Laimer M, Wolf HJ, Patsch JR \& Illsley NP 2002 Polar expression and phosphorylation of human leptin receptor isoforms in paired, syncytial, microvillous and basal membranes from human term placenta. Placenta 23 516-521.

Eligini S, Barbieri SS, Cavalca V, Camera M, Brambilla M, De Franceschi M, Tremoli E \& Colli S 2005 Diversity and similarity in signaling events leading to rapid COX-2 induction by tumor necrosis factor-alpha and phorbol ester in human endothelial cells. Cardiovascular Research 65 683-693.

Fasshauer M \& Paschke R 2003 Regulation of adipocytokines and insulin resistance. Diabetologia 46 1594-1603.

Fasshauer M, Kralisch S, Klier M, Lossner U, Bluher M, Klein J \& Paschke R 2003 Adiponectin gene expression and secretion is inhibited by interleukin-6 in 3T3-L1 adipocytes. Biochemical and Biophysical Research Communications 301 1045-1050.

Festa A, Shnawa N, Krugluger W, Hopmeier P, Schernthaner G \& Haffner SM 1999 Relative hypoleptinaemia in women with mild gestational diabetes mellitus. Diabetic Medicine 16 656-662.

Garcia-Arencibia M, Molero S, Davila N, Carranza MC \& Calle C 2005 17ß-Estradiol transcriptionally represses human insulin receptor gene expression causing cellular insulin resistance. Lenkemia Research 29 79-87.

Halleux CM, Takahashi M, Delporte ML, Detry R, Funahashi T, Matsuzawa Y \& Brichard SM 2001 Secretion of adiponectin and regulation of apM1 gene expression in human visceral adipose tissue. Biochemical and Biophysical Research Communications 288 1102-1107.

Hamilton BS, Paglia D, Kwan AY \& Deitel M 1995 Increased obese mRNA expression in omental fat cells from massively obese humans. Nature Medicine 1 953-956.

Haugen F, Jorgensen A, Drevon CA \& Trayhurn P 2001 Inhibition by insulin of resistin gene expression in 3T3-L1 adipocytes. FEBS Letters 507 105-108.

Henson MC \& Castracane VD 2000 Leptin in pregnancy. Biology of Reproduction 63 1219-1228. 
Hoggard N, Hunter L, Duncan JS, Williams LM, Trayhurn P \& Mercer JG 1997 Leptin and leptin receptor mRNA and protein expression in the murine fetus and placenta. PNAS $\mathbf{9 4}$ 11073-11078.

Hu E, Liang P \& Spiegelman BM 1996 AdipoQ is a novel adipose-specific gene dysregulated in obesity. Journal of Biological Chemistry 271 10697-10703.

Huang SW, Seow KM, Ho LT, Chien Y, Chung DY, Chang CL, Lai YH, Hwang JL \& Juan CC 2005 Resistin mRNA levels are downregulated by estrogen in vivo and in vitro. FEBS Letters $\mathbf{5 7 9}$ 449-454.

Kappes A \& Loffler G 2000 Influences of ionomycin, dibutyrylcycloAMP and tumour necrosis factor- $\alpha$ on intracellular amount and secretion of apM1 in differentiating primary human preadipocytes. Hormone and Metabolic Research 32 548-554.

Kaser S, Kaser A, Sandhofer A, Ebenbichler CF, Tilg H \& Patsch JR 2003 Resistin messenger RNA expression is increased by proinflammatory cytokines in vitro. Biochemical and Biophysical Research Communications 309 286-290.

Kim KH, Lee K, Moon YS \& Sul HS 2001 A cysteine-rich adipose tissue-specific secretory factor inhibits adipocyte differentiation. Journal of Biological Chemistry 276 11252-11256.

Kostadinova RM, Nawrocki AR, Frey FJ \& Frey BM 2005 Tumor necrosis factor alpha and phorbol 12-myristate-13-acetate down-regulate human 11 beta-hydroxysteroid dehydrogenase type 2 through $\mathrm{p} 50 / \mathrm{p} 50 \mathrm{NF}-\mathrm{\kappa B}$ homodimers and Egr-1. FASEB Journal 19 650-652.

Lappas M, Permezel M \& Rice GE 2004 Release of pro-inflammatory cytokines and 8-isoprostane from placenta, adipose tissue and skeletal muscle from normal pregnant women and women with gestational diabetes mellitus. Journal of Clinical Endocrinology and Metabolism 89 5627-5633.

Lea RG, Howe D, Hannah LT, Bonneau O, Hunter L \& Hoggard N 2000 Placental leptin in normal, diabetic and fetal growth-retarded pregnancies. Molecular and Human Reproduction 6 763-769.

Lepercq J, Cauzac M, Lahlou N, Timsit J, Girard J, Auwerx J \& Hauguel-de Mouzon S 1998 Overexpression of placental leptin in diabetic pregnancy: a critical role for insulin. Diabetes 47 847-850.

Lepercq J, Challier JC, Guerre-Millo M, Cauzac M, Vidal H \& Hauguel-de Mouzon S 2001 Prenatal leptin production: evidence that fetal adipose tissue produces leptin. Journal of Clinical Endocrinology and Metabolism 86 2409-2413.

Lindsay RS, Walker JD, Havel PJ, Hamilton BA, Calder AA \& Johnstone FD 2003 Adiponectin is present in cord blood but is unrelated to birth weight. Diabetes Care 26 2244-2249.

Lonnqvist F, Arner P, Nordfors L \& Schalling M 1995 Overexpression of the obese (ob) gene in adipose tissue of human obese subjects. Nature Medicine 1 950-953.

Lu SC, Shieh WY, Chen CY, Hsu SC \& Chen HL 2002 Lipopolysaccharide increases resistin gene expression in vivo and in vitro. FEBS Letters $\mathbf{5 3 0} 158-162$.

MacDougald OA, Hwang CS, Fan H \& Lane MD 1995 Regulated expression of the obese gene product (leptin) in white adipose tissue and 3T3-L1 adipocytes. PNAS 92 9034-9037.

Machinal F, Dieudonne MN, Leneveu MC, Pecquery R \& Giudicelli Y 1999 In vivo and in vitro ob gene expression and leptin secretion in rat adipocytes: evidence for a regional specific regulation by sex steroid hormones. Endocrinology 140 1567-1574.

Malmstrom R, Taskinen MR, Karonen SL \& Yki-Jarvinen H 1995 Insulin increases plasma leptin concentrations in normal subjects and patients with NIDDM. Diabetologia 39 993-996.

Masuzaki H, Ogawa Y, Sagawa N, Hosoda K, Matsumoto T, Mise H, Nishimura H, Yoshimasa Y, Tanaka I, Mori T et al. 1997 Nonadipose tissue production of leptin: leptin as a novel placenta-derived hormone in humans. Nature Medicine $\mathbf{3}$ 1029-1033.
Nuamah MA, Yura S, Sagawa N, Itoh H, Mise H, Korita D, Kakui K, Takemura M, Ogawa Y, Nakao K et al. 2004 Significant increase in maternal plasma leptin concentration in induced delivery: a possible contribution of pro-inflammatory cytokines to placental leptin secretion. Endocrine Journal 51 177-187.

Pighetti M, Tommaselli GA, D’Elia A, Di Carlo C, Mariano A, Di Carlo A \& Nappi C 2003 Maternal serum and umbilical cord blood leptin concentrations with fetal growth restriction. Obstetrics and Gynecology $102535-543$.

Ranheim T, Haugen F, Staff AC, Braekke K, Harsem NK \& Drevon CA 2004 Adiponectin is reduced in gestational diabetes mellitus in normal weight women. Acta Obstetrica et Gynecologica Scandinavica $\mathbf{8 3}$ 341-347.

Saladin R, De Vos P, Guerre-Millo M, Leturque A, Girard J, Staels B \& Auwerx J 1995 Transient increase in obese gene expression after food intake or insulin administration. Nature 377 527-529.

Schwartz MW, Prigeon RL, Kahn SE, Nicolson M, Moore J, Morawiecki A, Boyko EJ \& Porte D Jr 1997 Evidence that plasma leptin and insulin levels are associated with body adiposity via different mechanisms. Diabetes Care 20 1476-1481.

Shojima N, Sakoda H, Ogihara T, Fujishiro M, Katagiri H, Anai M, Onishi Y, Ono H, Inukai K, Abe M et al. 2002 Humoral regulation of resistin expression in 3T3-L1 and mouse adipose cells. Diabetes 51 1737-1744.

Soh EB, Mitchell MD \& Keelan JA 2000 Does leptin exhibit cytokine-like properties in tissues of pregnancy? American Journal of Reproductive Immunology 43 292-298.

Steppan CM, Bailey ST, Bhat S, Brown EJ, Banerjee RR, Wright CM, Patel HR, Ahima RS \& Lazar MA 2001 The hormone resistin links obesity to diabetes. Nature 409 307-312.

Voon DC, Subrata LS, Karimi M, Ulgiati D \& Abraham LJ 2004 TNF and phorbol esters induce lymphotoxin-beta expression through distinct pathways involving Ets and NF-kappa B family members. Journal of Immunology 172 4332-4341.

Wang XF, Wang QD, Hu WQ \& Evers BM 2004 Regulation of phorbol ester-mediated TRAF1 induction in human colon cancer

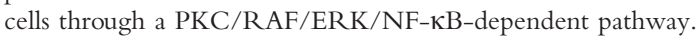
Oncogene 23 1885-1895.

Wauters M, Considine RV \& Van Gaal LF 2000 Human leptin: from an adipocyte hormone to an endocrine mediator. European Journal of Endocrinology 143 293-311.

Way JM, Gorgun CZ, Tong Q, Uysal KT, Brown KK, Harrington WW, Oliver WR, Willson TM, Kliewer SA \& Hotamisligil GS 2001 Adipose tissue resistin expression is severely suppressed in obesity and stimulated by peroxisome proliferator-activated receptor gamma agonists. Journal of Biological Chemistry 276 25651-25653.

Weyer C, Funahashi T, Tanaka S, Hotta K, Matsuzawa Y, Pratley RE \& Tataranni PA 2001 Hypoadiponectinemia in obesity and type 2 diabetes: close association with insulin resistance and hyperinsulinemia. Journal of Clinical Endocrinology and Metabolism $\mathbf{8 6}$ 1930-1935.

Williams MA, Qui C, Muy-Rivera M, Vadachkoria S, Song T \& Luthy DA 2004 Plasma adiponectin concentrations in early pregnancy and subsequent risk of gestational diabetes mellitus. Journal of Clinical Endocrinology and Metabolism 89 2306-2311.

Yura S, Sagawa N, Itoh H, Kakui K, Nuamah MA, Korita D, Takemura M \& Fujii S 2003 Resistin is expressed in the human placenta. Journal of Clinical Endocrinology and Metabolism $\mathbf{8 8}$ 1394-1397.

Received in final form 27 May 2005

Accepted 24 June 2005

Made available online as an Accepted Preprint

1 July 2005 